Vol. 59: e16160046, January-December 2016 http://dx.doi.org/10.1590/1678-4324-2016150046 ISSN 1678-4324 Online Edition
BRAZILIAN ARCHIVES OF

BIOLOGY AND TECHNOLOGY

AN INTERNATIONAL JOURNAL

\title{
Investigation of the GJB6 Deletion Mutations Del (GJB6- D13s1830) and Del (GJB6-D13s1854) in Iranian Patients with Autosomal-Recessive Non-Syndromic Hearing Loss (ARNSHL)
}

\author{
Habib Onsori ${ }^{1 *}$. \\ ${ }^{1}$ Cell \& Molecular Biology, Islamic Azad University, Marand Branch, Iran Marand, Iran.
}

\begin{abstract}
Hearing loss (HL) is the most common inherited sensory disorder affecting about 1 in 1000 births. The first locus for nonsyndromic autosomal recessive HL is on chromosome 13q11-22. The two genes, GJB2 and GJB6, are closely located on chromosome and are known to be co-expressed in the embryonic cochlea. Deletion mutations involving GJB6 were associated with autosomal-recessive nonsyndromic hearing loss (ARNSHL) and in combination with a GJB2 mutation with digenic ARNSHL. The objective of this study was to screen for the del (GJB6-D13S1830) and del (GJB6-D13s1854) mutations in GJB6 gene in patients with ARNSHL from Iran, using multiplex PCR and direct sequencing methods. Agarose gel electrophoresis and DNA sequencing of amplified fragment of the PCR reaction showed none of the patients was found to carry deletion in GJB6 gene which indicates that these deletions are restricted to certain populations and indicating a founder effect regarding these deletions.
\end{abstract}

Key words: Hearing loss, GJB6, GJB2, Deletion Mutation, Iran.

${ }^{1}$ Author for correspondence: onsoribiomol@marandiau.ac.ir 


\section{INTRODUCTION}

Hearing loss (HL) is a common sensory deficit in humans and most auditory system dysfunctions resulting in HL are genetically inherited (Wang et al. 2011). The incidence of congenital HL is about 1 in 1000 births. It is estimated that over 100 genes may be involved in nonsyndromic genetic deafness, and of these, approximately $80 \%$ are associated with autosomal recessive, $15 \%$ autosomal dominant, 1 to $3 \%$ chromosome $\mathrm{X}$, and 0.5 to $1 \%$ mitochondrial mutations (Moriera et al. 2015).

In many populations, up to $50 \%$ of all cases of ARNSHL are caused by mutations in the DFNB1 locus (MIM 220290) on 13q12.4. This locus contains the GJB2 gene (MIM 121011), encoding connexin-26 (Cx26), which belongs to a family of transmembrane proteins with about 20 members in humans (Kelsell et al. 1997).

A large number of affected subjects with only one GJB2 mutant allele complicate the molecular diagnosis of DFNB1 deafness. There are other mutations in the DFNB1 locus but outside the GJB2 gene. Deletions in the DFNB1 locus outside GJB2, but truncating the neighbouring GJB6 gene (MIM 604418), which encodes connexin-30 (Cx30), another component of the gap junction networks of the cochlea (Lerer et al. 2001).

Gap junction channels intercede direct cell-tocell communication by enabling intracellular transport of small biological molecules, including electrolytes, second messengers and metabolites. The connexins are a family of proteins that form GJ channels in vertebrates (Chang et al. 2003; Beyer et al. 2009). Intercellular communication via gap junctions is critical for auditory function. The important role of intercellular communication, particularly that between GJB2 and GJB6 (encoding CX26 and CX30), has been established by evidence that certain connexin gene mutations cause sensorineural HL (Yung et al. 2010).

The GJB6 gene (AJ005585) encodes a 261amino acid protein. In some populations, GJB6 mutations, including DFNB1 and DFNA3, reportedly cause HL. The GJB6 deletion mutations del (GJB6-D13S1830) and del (GJB6-D13s1854) have been associated with HL in some countries (Batissoco et al.
2009; Wang et al. 2011; del Castillo et al. 2003).

The previous study, the occurrence of $35 \mathrm{delG}$ and other point mutations in the GJB2 gene in patients with ARNSHL in Marand in the Northwest of Iran were identified. Six different mutations in the GJB2 gene including 35delG, R184P, R216K, 363delC, C202R and V84M were identified in the subjects. Therefore, mutations in the CX26 gene were found in $20 \%$ of the patients. Among these mutations, the $35 \mathrm{delG}$ was the most common mutation found in 5 out of 50 cases with $6 \%$ allelic frequency (Onsori 2015).

Given the high prevalence of deafness in Marand, Iran, this study investigates the GJB6 deletion mutations del(GJB6-D13S1830) and del(GJB6-D13s1854) in ARNSHL patients with no mutations in GJB2 gene or were heterozygous.

\section{MATERIALS AND METHODS}

\section{Subjects}

To meet the purpose of the study, 50 unrelated patients with ARNSHL (either heterozygous or negative for a GJB2 mutation) were selected. This research project has been approved by ethical committee.

\section{Genomic DNA Extraction and PCR}

After taking written informed consent, blood samples were obtained. Genomic DNA was extracted from $1 \mathrm{ml}$ of EDTA anticoagulated peripheral blood by rapid genomic DNA extraction (RGDE) method (Onsori et al. 2014).

For analyzing the deletion mutations in the GJB6 gene, multiplex PCR used based on del Castillo's definithion (del Castillo et al. 2005). The primers used in the multiplex PCR assay were GJB6-1R, 5'TTTAGGGCATGATTGGGGTGATTT-3', and BKR-1, 5'CACCATGCGTAGCCTTAACCATTTT-3' (for amplification of the del(GJB6-D13S1830) breakpoint junction); DelBK1, 5'TCATAGTGAAGAACTCGATGCTGTTT-3', and DelBK2, 5'CAGCGGCTACCCTAGTTGTGGT-3' (for amplification of the del(GJB6-D13S1854) breakpoint junction); Cx30Ex1A, 5'CGTCTTTGGGGGTGTTGCTT-3', and Cx30Ex1B, and 
CATGAAGAGGGCGTACAAGTTAGAA-3' (to amplify GJB6 exon 1).

PCR reactions were carried out in $20 \mu \mathrm{L}$ reaction mixture as final volume containing $0.2 \mathrm{mM}$ dNTP, 10 pmoles of each primer, 1.5 $\mathrm{mM} \mathrm{MgCl2}, 0.5 \mathrm{U}$

of Taq DNA polymerase, $1 \times$ PCR buffer, and about $1 \mu \mathrm{g}$ of genomic DNA on a SENSOQUEST (Labcycler/Germany) Thermal Cycler.

PCR was performed under the following conditions: One cycle of denaturation at $96^{\circ} \mathrm{C}$ for five minutes; five touchdown cycles of denaturation at $94^{\circ} \mathrm{C}$ for $50 \mathrm{~s}$, and annealing for $45 \mathrm{~s}$ at $65^{\circ} \mathrm{C}$ for the first cycle and a $1^{\circ} \mathrm{C}$ reduction per cycle; 25 cycles of denaturation at $94^{\circ} \mathrm{C}$ for 50 seconds, and annealing at $60^{\circ} \mathrm{C}$ for $45 \mathrm{~s}$; and a final extension step of $72^{\circ} \mathrm{C}$ for seven min. The amplified fragments were run on $1.5 \%$ agarose gel by safe dye staining.

\section{Sequencing and Sequence analyzing}

Expected PCR products [with 333bp length for GJB6 exon1, 460 bp for del(GJB6-D13S1830) and 564 bp for del(GJB6-D13S1854)] were subjected to direct sequencing in both directions. The position of the PCR products on agarose gel corresponds to the deletion breakpoint junctions and to GJB6 exon 1. The sequencing results were analyzed by sequencing-analysis Chromas Lite 2.1 software and were compared with the wild type.

\section{RESULTS AND DISCUSSION}

Out of the 50 unrelated ARNSHL studied samples, no deletions of GJB6 gene were found and all the individuals showed the normal 333bp amplified fragment band on agarose gel (Fig. 1). Direct sequencing of PCR product confirmed the identity of GJB6 exon 1 and validated the test (Fig. 2).

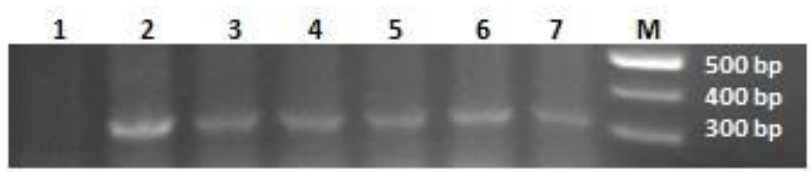

Figure1- A part of $1.5 \%$ agarose gel electrophoresis showing the position of the PCR products corresponding to the GJB6 exon 1. Lanes from left to right are: 1: Negative control; 2-7 patients and M: Molecular weight standard Marker.

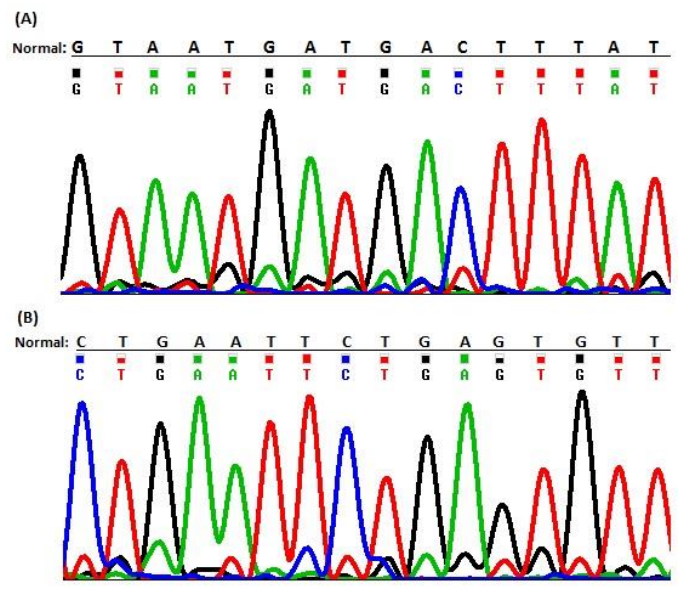

Figure 2- A and B two parts of DNA sequence of the GJB6 exon 1 indicating no GJB6 deletion mutations.

Although more than 100 genes involved in the development of HL, GJB2 gene is listed as main cause of deafness in different populations and 35delG mutation is the most common mutation in this gene in many populations. However, this mutation is rare in some East Asian peoples (Zelante et al. 1997; Kenneson et al. 2002). Connexins 26 and 30 are extremely expressed in epithelial supporting cells of the mammalian cochlea and are said to play a key role in the cycling of potassium from the hair cells back to the endolymph (Batissoco et al. 2009).

Whereas biallelic mutations in the GJB2 gene account for $50 \%$ of ARNSHL, a large number of cases with a single mutation are left mysterious by screening GJB2 alone. The GJB6 gene maps adjacent to GJB2 at the DFNB1 locus, and two large deletions [one of $309 \mathrm{~kb}$, del(GJB6-D13S1830) and another of $232 \mathrm{~Kb}$, del(GJB6-D13S1854)] upstream the GJB2 gene are frequently found among deaf individuals in Spain (Del Castillo et al. 2002; 2003).

These deletion mutations in trans with mutations in the GJB2 gene provide an explanation for HL. Since the frequencies of these deletions varied from 5 to $15 \%$ in individuals with only one detected mutation in GJB2 gene, finding the GJB6 deletion mutations in heterozygous individuals to GJB2 has been and still is the goal of researchers around the world (Del Castillo et al. 2003). As a result, the researcher's central focus in this study is to investigate the common deletion mutations in CX30 gene.

Previous studies in some countries have shown that, the del(GJB6-D13S1830) mutation is 
most common in Spain, France, the United Kingdom, Israel, and Brazil but less frequent in the USA, Belgium, and Australia, and very rare in southern Italy (del Castillo et al. 2003). However, recent studies in have found that the deletion is present in northern Italy at frequencies like to those of other European countries (Gualandi et al. 2004). Still, there are other studies showing that this deletion mutation was also found in other countries such as Germany (Bolz 2004) and USA (Pandya 2003), but not in Austria (Gunther et al. 2003), China (Liu et al. 2002), or Turkey (Tekin et al. 2003; Uyguner et al. 2003).

Still, there are some other studies show that the del(GJB6-D13S1830) mutation, found in many populations over the world, is much more frequent than del(GJB6-D13S1854), which is for the present restricted to a few countries (del Castillo et al. 2004).

In addition, several studies conducted in Iran did not reveal any mutation in GJB6 that was associated with ARNSHL (Jabbarpour Bonyadi 2006;Tabataeifar et al. 2010). The absence of GJB6 deletions found in this study strongly corresponds with those of the above. In conclusion, it can be said that the types and frequencies of mutations are intensely influenced by the ethnic composition of the population. Moreover, hereditary HL is genetically extremely heterogeneous and every year other loci are found to be associated with hereditary HL. The present study suggests massive parallel sequencing (MPS) for HL patients with the use of gene panels that contain HL causal genes.

\section{ACKNOWLEDGMENTS}

This study was supported by a Grant of Marand branch, Islamic Azad University. The researcher thanks all patients and their families for their cooperation in this research.

\section{REFERENCES}

Batissoco AC, Abreu-Silva RS, Celia Braga MC, Lezirovitz K, Della-Rosa V, Alfredo T, et al. Prevalence of GJB2 (Connexin-26) and GJB6 (Connexin-30) Mutations in a Cohort of 300 Brazilian Hearing-Impaired Individuals: Implications for Diagnosis and Genetic Counseling. Ear Hear. 2009; 30;1-7.

Beyer EC, Berthoud VM. The family of connexin gene. In Harris A, Locke D, eds. Connexin: $A$
Guide, Humana Press, Springer, US. 2009; 326.

Bolz H, Schade G, Ehmer S, Kothe C, Hess M, Gal A. Phenotypic variability of non-syndromic hearing loss in patients heterozygous for both c.35delG of GJB2 and the 342-kb deletion involving GJB6. Hear Res. 2004; 188: 42-46.

Chang EH, Van Camp G, Smith RJ. The Role of Connexins in Human Disease. Ear Hear. 2003; 24(4): 314-323.

Del Castillo FJ, Rodriguez-Ballesteros M, Alvarez A, Hutchin T, Leonardi E, de Oliveira CA, et al. A novel deletion involving the connexin-30 gene, del(GJB6- d13s1854), found in trans with mutations in the GJB2 gene (connexin-26) in subjects with DFNB1 non-syndromic hearing impairment. J Med Genet. 2005; 42: 588-594.

Del Castillo I, Moreno-Pelayo MA, del Castillo FJ, Brownstein Z, Marlin S, Adina Q, et al. Prevalence and evolutionary origins of the del(GJB6-D13S1830) mutation in the DFNB1 locus in hearing-impaired subjects: a multicenter study. Am J Hum Genet. 2003; 73: 1452-1458.

Del Castillo I, Villamar M, Moreno-Pelayo MA, Del Castillo FJ, Alvarez A, Telleria D, et al. A deletion involving the connexin 30 gene in nonsyndromic hearing impairment. $N$ Engl $J$ Med. 2002; 346: 243-249.

Gualandi F, Ravani A, Berto A, Burdo S, Trevisi P, Ferlini A, et al. Occurrence of del(GJB6D13S1830) mutation in Italian nonsyndromic hearing loss patients carrying a single GJB2 mutated allele. Acta Otolaryngol Suppl. 2004; 552: 29-34.

Gunther B, Steiner A, Nekahm-Heis D, Albegger $\mathrm{K}$, Zorowka P, Utermann G, et al. The 342-kb deletion in GJB6 is not present in patients with nonsyndromic hearing loss from Austria. Hum Mutat. 2003; 22: 180-183.

Jabbarpour Bonyadi M, Esmaeili M, Younespour $\mathrm{R}$, Lotfalizadeh N, Absavaran A. Analysis of Common Mutations in GJB2 and GJB6 Genes in Patients with Autosomal Recessive Nonsyndromic Hearing Loss in Eastern Azarbaijan. ZUMS J. 2006; 14 (55): 30-38.

Kelsell DP, Dunlop J, Stevens HP, Lench NJ, Liang JN, Parry G, et al. Connexin 26 mutations in hereditary nonsyndromic sensorineural deafness. Nature. 1997; 387: 8083.

Kenneson A, Van Naarden Braun K, Boyle C. GJB2 (connexin 26) variants and nonsyndromic sensorineural hearing loss: a HuGE review. Genet Med. 2002; 4: 258-274.

Lerer I, Sagi M, Ben-Neriah Z, Wang T, Levi H, Abeliovich D. A deletion mutation in GJB6 cooperating with a GJB2 mutation in trans in non-syndromic deafness: a novel founder mutation in Ashkenazi jews. Hum Mutat. 2001; 18: 460 . 
Onsori H. Study of Cx26 gene mutations in patients with non-syndromic sensorineural hearing loss. Feyz. 2015; 19(3): 242-248.

Onsori H, Rahmati M, Fazli D. A Novel De Novo Dominant Mutation in GJB2 Gene Associated with a Sporadic Case of Nonsyndromic Sensorineural Hearing Loss. Iranian J Publ Health. 2014; 43(12): 1710-1713.

Liu XZ, Xia XJ, Ke XM, Ouyang XM, Du LL, Liu $\mathrm{YH}$, et al. The prevalence of connexin 26 (GJB2) mutations in the Chinese population. Hum Genet. 2002; 111: 394-397.

Pandya A, Arnos KS, Xia XJ, Welch KO, Blanton $\mathrm{SH}$, Friedman TB, et al. Frequency and distribution of GJB2 (connexin 26) and GJB6 (connexin 30) mutations in a large North American repository of deaf probands. Genet Med. 2003; 5: 295-303.

Moreira D, Da Silva D, Lopez P, Mantovani JC. Screening of Connexin 26 in Nonsyndromic Hearing Loss. Int Arch Otorhinolaryngol. 2015; 19: 30-33.

Tabatabaiefar MA, Montazer Zohour M, Shariati L, Saffari Chaleshtori J, Ashrafi K, Gholami A, et al. Mutation Analysis of GJB2 and GJB6 Genes and the Genetic Linkage Analysis of Five Common DFNB Loci in the Iranian Families with Autosomal Recessive Non-Syndromic Hearing Loss. J Sciences. 2010; 21(2): 105112.
Tekin M, Duman T, Bogoclu G, Incesulu A, Comak E, Ilhan I, et al. Spectrum of GJB2 mutations in Turkey comprises both Caucasian and Oriental variants: roles of parental consanguinity and assortative mating. Hum Mutat. 2003; 21: 552-553.

Uyguner O, Emiroglu M, Uzumcu A, Hafiz G, Ghanbari A, Baserer N, et al. Frequencies of gap- and tight-junction mutations in Turkish families with autosomal-recessive nonsyndromic hearing loss. Clin Genet. 2003; 64: 65-69.

Wang WH, Liu YF, Su CC, Su MC, Li SY, Yang JJ. A Novel Missense Mutation in the Connexin30 Causes Nonsyndromic Hearing Loss. PLoS ONE. 2011; 6(6): e21473.

Yang JJ, Wang WH, Lin YC, Weng HH, Yang JT, Hwang $\mathrm{CF}$ et al. Prospective variants screening of connexin genes in children with hearing impairment: genotype/phenotype Correlation. Hum Genet. 2010; 128: 303-313.

Zelante L, Gasparini P, Estivill X, Melchionda S, D'Agruma L, Govea N, et al. Connexin 26 mutations associated with the most common form of non-syndromic neurosensory autosomal recessive deafness (DFNB1) in mediterraneans. Hum Mol Genet. 1997; 6: 1605-1609.

Received: January 252015 Accepted: January 272015 


\section{Erratum}

In the 01 page, that read:

\section{"Sheikh Khursheed", Desh Raj"”}

Read:

\section{"Habib Onsori2*."}

In the 01 page, that read:

"1 SKUAST-K, Entomology, Shalimar Shalimar, Srinagar, India; 2, CSKHP Agricultural University, Entomology Palampur, Himachal Pradesh, India

"

Read:

"Cell \& Molecular Biology, Islamic Azad University, Marand Branch, Iran Marand, Iran"

In the 01 page, that read:

"1 Author for correspondence: sheikhento@ gmail.com"

Read:

“1 Author for correspondence: onsoribiomol@marandiau.ac.ir" 